pp. $819-827$

\title{
The Role of Social Entrepreneurship in Ensuring the Social Security of the State
}

\author{
Submitted 06/06/20, $1^{\text {st }}$ revision 24/07/20, $2^{\text {nd }}$ revision 28/08/20, accepted 15/09/20 \\ Tatyana Romanova ${ }^{1}$, Venelin Terziev ${ }^{2}$, Olga Andreeva ${ }^{3}$, Anna Sukhoveeva ${ }^{4}$, \\ Popova Galina ${ }^{5}$, Otrishko Marina ${ }^{6}$
}

\section{Abstract:}

Purpose: The article considers social entrepreneurship as a tool for ensuring social security - a promising option for solving various problems of modern society (unemployment, including vulnerable groups of the population, social adaptation, personal self-realization, selfsufficiency, etc.).

Design/Methodology/Approach: The authors highlight the need to create the necessary prerequisites for expanding the business activity of social entrepreneurship through the implementation of scientifically sound and well-formulated state incentive policy

Findings: the results of the analysis of the terminological field of social entrepreneurship are presented.

Practical Implications: a clear understanding of the economic boundaries of social entrepreneurship will create an adequate le gal framework for its functioning and form criteria for referring to it for the possibility of participating in competitive and grant projects to obtain extra funding.

Originality/Value: in the context of social security, the problem of social entrepreneurship has not been previously studied, while it has significant potential in light of the need to improve the quality of life of citizens (especially complicated by the negative consequences of the spread of the coronavirus infection COVID-19), which, of course, is an essential component of social security.

Keywords: Social entrepreneurship, social security, social innovation, public policy.

JEL codes: L31, L38, O35.

Paper type: Research article.

\footnotetext{
${ }^{1}$ Rostov State University of Economics, Department of Finance, Rostov-on-Don, Russian Federation, kafedra_finance@mail.ru

${ }^{2}$ University of Rousse, Bulgaria, ORCID: 0000-0003-1115-8877, terziev@ skmat.com;

${ }^{3}$ Corresponding author, Rostov State University of Economics, Center for Strategic Research of Socio-Economic Development of the South of Russia, Rostov-on-Don, Russian Federation, ORCID: 0000-0002-5567-6396, olvandr@yandex.ru.

${ }^{4}$ Rostov State University of Economics, Department of Finance, Rostov-on-Don, Russian Federation,suhoveeva.anna@mail.ru;

${ }^{5}$ Rostov State University of Economics, Department of Finance, Rostov-on-Don, Russian Federation, galina.popova127@mail.ru;

${ }^{6}$ Rostov State University of Economics, Department of Finance, Rostov-on-Don, Russian Federation,starka13@mail.ru;
} 


\section{Introduction}

National security consists in ensuring the sustainability of the country's socioeconomic development. In turn, the sustainable socio-economic development of the country presupposes the maintenance of economic security, which is manifested, inter alia, in the stimulation of entrepreneurship, in general, and social entrepreneurship, in particular. Social entrepreneurship is a direction of social development that is relatively new and, therefore, of scientific interest. The scientific and cognitive problem lies in the fact that social entrepreneurship is a combination of two different, even in some respects opposite, concepts, since entrepreneurs are focused on profit, and the social component is associated with meeting social needs.

But the modern understanding of social development determines the goals of entrepreneurs' activities not as exclusively corporate, but as socially responsible for the whole society. Social entrepreneurship is one of the main conditions for the socioeconomic development of the country and the achievement of its social security. The development of the social structure and relations in society, the system of life support and socialization of people, the way of life in accordance with the needs of progress, current and future generations determine the content of social security - an essential element of national security. The level and quality of life of citizens are the most important indicators for assessing the real socio-economic consequences of the reforms and the degree of social tension in society.

Social security is the key goal of all state policy and the most important part of the state's new strategy. It could be provided with the help of social entrepreneurship as a promising option for solving various problems of modern society (unemployment, including vulnerable groups of the population, social adaptation, personal selfrealization, self-sufficiency, etc.). In this regard, an urgent task is to create the necessary prerequisites for expanding the business activity of social entrepreneurship through the implementation of a scientifically grounded and well-formulated state incentive policy. And for this, it is necessary to clearly define the economic boundaries of social entrepreneurship, which in turn will create an adequate legal framework for its functioning and form criteria for referring to it for the possibility of participating in competitive and grant projects to obtain additional funding.

\section{Methodology}

Social entrepreneurship in economic science, according to researchers, is a promising sector of entrepreneurship, containing quite a few problems both in terms of theoretical research and in terms of practical research. The very concept of social entrepreneurship is quite new, in its modern form it is not more than twenty years old. This new economic phenomenon has confirmed its practical importance. At the same time, there are still quite a lot of disagreements in terms of the terminology of social entrepreneurship: criteria and definitions, a practical research base. In the context of social security, the problem of social entrepreneurship has not been previously 
studied, while it has significant potential in light of the need to improve the quality of life of citizens (especially complicated by the negative consequences of the spread of the coronavirus infection COVID-19), which, of course, is an essential component of social security.

The methodology used by the United Nations includes eight categories in the Concept of Human Security, among which social security is highlighted. We believe that freedom from need and poverty, as a component of social security, according to this approach, could be achieved through the sphere of social entrepreneurship, in which often the most vulnerable citizens are involved.

In preparing the article, a systematic approach, analysis and synthesis, and generalizations were applied. An analysis of various points of view of Russian and foreign authors was carried out to substantiate the need for further scientific research in this area.

Using the "social entrepreneurship" concept, the authors believed that this is a new way of socio-economic activity, which combines the social purpose of the organization with entrepreneurial innovation and the achievement of sustainability of self-sufficiency. It is based on the functioning of the so-called social economic entities, created with the aim of solving a specific social problem or problems operating on the basis of innovation, financial discipline and business practices adopted in the commercial sector. Social entrepreneurship is a process, an activity, and social business entities are its organizational structures, within the framework of which their respective activities are reproduced and a social, economic and financial result is achieved.

\section{Results}

The roots of social entrepreneurship lie in classical entrepreneurship, which, as a rule, is understood as the proactive independent activity of citizens aimed at making profit or personal income, carried out on their own behalf, under their property responsibility or on behalf and under the legal responsibility of a legal entity. The term "social entrepreneurship" was first mentioned in foreign literature in the 1960s of the twentieth century, when this phenomenon began to be viewed as a purposeful way to solve social problems, as well as a phenomenon capable of causing not only economic, but also social changes. He assumes that people are united in a kind of group, living and / or working together (Kickul, 2014), as well as that society is placed above the individual.

As a rule, social problems are associated with such negative phenomena of humanity as crime, drunkenness, drugs, disruption of the functions of a specific social institution (for example, family, school), one of the forms of social conflict (national, labor), lack of funds at the disposal of society, to meet the urgent needs of people (in housing, health care, recreation). The aforementioned have served to increase the popularity of 
ideas of social entrepreneurship, and the concept of "social entrepreneurship" has become more stable, becoming more widespread in the 70s-80s of the last century and still attracting the attention of scientists, practitioners, government officials in many countries and continuing to actively develop in modern conditions (Stoffers, 2018; Barinova, 2018; Ivaschenko, 2019).

Makarevich and Sazonova (2012) defined the essence of social entrepreneurship as a new way of economic activity with the following features:

$>$ the social purpose of the organization, i.e. the social effect is a pre-planned and expected result, and not a side effect, as it happens in ordinary commercial entrepreneurship. Such enterprises are initially created to achieve socially significant goals, manifested in the creation of jobs (including for the disabled ones), training (including adults), etc.;

$>$ entrepreneurial innovation, which could be realized by using a new idea or a new combination of resources (including those that are not very attractive from the market point of view) to solve a social problem;

$>$ achieving sustainable self-sufficiency by generating income from the sale of the results of activities (goods and services), as well as through grants and charitable donations.

The experience of the world community shows that the search for economic instruments for solving acute social problems was actively pursued in various countries. This search led to the development of the concept of social entrepreneurship in the 80-90s. of the XX century. Researchers attribute this to the following reasons:

$>$ the increased role of human capital in ensuring sustainable socio-economic development;

$>$ an increase in the level of education, life and the level of well-being of the population;

$>$ the formed ideological aspect of understanding the need to solve social problems by society and the state.

This is what, in our opinion, determines the appeal to the concept of social security, which should consider the influence of these factors when developing the public policy (Nikulina, 2017; Yakovets, 2017). Modern market relations, characterized by economic uncertainty, in which the economy and the social sphere are involved, actualize social entrepreneurship as a special type of entrepreneurial activity aimed at a qualitative solution or mitigation of social problems in society (Inzelt, 2017; Plotnikov, 2019; Romanova, 2020).

Initially, social entrepreneurship developed and was defined as a special type of activity that fundamentally differs from commercial entrepreneurship in its objectives. In this regard, Stoffers et al. (2018) note that the goal of social entrepreneurship is "to 
create social value for society, while commercial entrepreneurship is aimed at maintaining profitable operations for personal purposes."

To understand the whole essence of the social entrepreneurship and social entrepreneur concepts, it is necessary to refer to the definitions given by international organizations promoting social entrepreneurship in general and support social entrepreneurs in particular. The most reputable organizations include the following: Schwab Foundation, Skoll Foundation, Social Enterprise London, The Social Enterprise Coalition, Ashoka Foundation. So, the Schwab Foundation discloses the content of the term "social entrepreneurship" as:

- applying practical, innovative and sustainable methods for the benefit of society;

- a unique approach to economic and social problems;

- activity based on the values and processes common to social entrepreneurs, in whatever field they work and regardless of whether they create a commercial or non-profit organization.

Social entrepreneur is a pragmatic visionary one who drives wide-ranging, systematic, and sustainable social change. Science offers various conceptual approaches to defining social entrepreneurship. For some researchers, social entrepreneurship is the activity of non-profit organizations looking for alternative strategies of resource provision, for others it is a special form of social responsibility of enterprises in the commercial sector choosing a strategy of intersectoral interaction and corporate citizenship, for others it is a catalyst of social change to address pressing social problems.

The researchers distinguish two academic schools that offer different approaches to the concept of social enterprise. In the definition of the first school, a social enterprise is a public organization aimed at creating social and financial benefits, with social impact and the amount of income being the main and equivalent criteria for activity. The principle of operation is based on the formula:

\section{Entrepreneurship + Innovation + Profitable Activities = Social Entrepreneurship}

In the definition of the second scientific school, a social enterprise is considered as a public organization aimed at creating social benefits, but using business processes in its activities as a tool to achieve goals. In this definition, social and financial goods are not equal values.

The most frequently cited definition and content of social entrepreneurship belongs to the Director of the Center for the Development of Social Entrepreneurship at Duke University in the United States, Gregory Dees (2001). He reveals the essence of social entrepreneurship as follows: social entrepreneurship "combines a passion for social mission with business discipline, innovation and determination." 
There are other approaches to defining social entrepreneurship (Dikovitskaya, 2019; Golovko, 2019). So, for example, Yu.N. Arai (2013) proposes to divide all definitions given by different authors into two large groups - definitions of social entrepreneurship in a narrow and broad sense. The first group includes those that characterize social entrepreneurship as the application of innovative approaches by non-profit organizations in order to generate income. The definitions of social entrepreneurship in a broad sense emphasize more general features of social entrepreneurship: it is understood as socially oriented innovation activity both in the commercial (socially oriented commercial companies, corporate social entrepreneurship) and in the non-profit sector, or on the junction - in mixed-type organizations.

The following characteristics are cited as essential features of social entrepreneurship: the predominance of a social mission over a commercial one (that is, purposeful solution of social problems); self-sufficiency and financial independence of enterprises (although grants and other sources of financing are allowed as additional sources of financing); innovative, entrepreneurial approach to problem solving; ethical integrity of the leader and the culture of the organization.

This approach provides a number of features that are inherent in social entrepreneurship:

$>$ the primacy of the social mission over commerce, which means that the enterprise is intended to solve a real social problem or to significantly reduce its severity. It should be borne in mind that the social effect is not a by-product of activity, as in entrepreneurship, but a goal-directed result (in turn, this determines the direction of the profit obtained for the social goals of the organization, and not in the wallets of investors or owners);

$>$ a sustainable commercial effect that ensures the self-sufficiency and competitiveness of the enterprise;

$>$ innovation combining social and economic resources, without which neither the sustainability of the social mission, nor the economic sustainability are possible.

It should be noted that it is the undesirable social order that has developed in the state in some area that could be a natural prerequisite for the emergence of non-standard socio-economic organizations, such as social enterprises (Morozov, 2019; Schultz, 2020). Otherwise, the social problem would have already been solved by means of traditional sectors of the economy - public, private, or non-profit. Examples of undesirable "social order" could be like persistent unemployment, environmentally harmful production, social exclusion of disabled people, the decline of traditional settlements, etc. Social entrepreneurship could quite solve these problems by introducing into the economic circulation resources that were not previously attracted in this capacity (Bacq, 2018). 
Achieving social security involves solving a complex problem of linking the economic efficiency of business organizations with public needs to mitigate social problems (Ferova, 2019). This puts commercial, non-profit organizations and the state in front of the need to change their role in the field of social security and solving social problems.

\section{Conclusions}

Strengthening social security will ensure the implementation of the strategic goals of the state's social policy: the development of the economic and social capacity of the state, the implementation of guarantees of citizens' rights in the field of labor, education, culture, health, improving the quality of life, the index of social well-being and social moods of citizens. Indeed, the emergence of new risks, such as in the current situation of the impact of coronavirus consequences, requires the search for innovative ways to minimize them.

The principles of state policy for achieving national security goals in the field of entrepreneurship should be the following: division of responsibilities between state authorities in providing assistance to medium and small businesses; responsibility of federal government bodies for the correct conduct of business, the creation of the necessary conditions for the economic development of business entities.

So, in Russia, work started on the formation of the Register of Social Entrepreneurs, which immediately caused a huge number of difficulties for its participants: a complex procedure for preparing the necessary documents, formalities, due to which it is impossible to be included into the register with a general understanding of the importance of the activities carried out, etc. This tool is, among other things, a condition for enhancing the social security of the entire state, since the well-being of its individual citizens and entrepreneurs who seek to solve social problems, and therefore make the quality and standard of living higher, forms the well-being of the whole society.

We consider it necessary to consider the influence of the following trends when developing state policy in the field of social security:

- low susceptibility of some social problems to traditional measures of influence used in the public and non-profit sectors in relation to poverty, unemployment, social exclusion and other problems of vulnerable groups of the population;

- deepening inequality between social groups and countries, which began to threaten socio-economic, financial and political crises;

- the stability of the coexistence in each country of market and non-market, developed and undeveloped segments of social and economic life, which began to be viewed in some cases as a barrier, and in others as an underutilized resource for development; 
- the expansion of the social needs of the population, especially in developed countries, both in size and diversity - hence the need for individualization and diversification of social services;

- an increase in the number of non-profit organizations and competition between them for the resources of the state and charity foundations (this process, on the one hand, leads to a lack of resources in small or newly created organizations, and on the other, to the concentration of donor funds from the largest and most working the time of non-profit organizations, which often turns into their bureaucratization;

- commercialization of public services and, as a result, increased competition between non-profit organizations and businesses in meeting public needs, which non-profit organizations often lose;

- negative consequences of the spread of coronavirus infection, which, on the one hand, contributes to the expansion of the scope of activities of social entrepreneurs, since social problems become more diverse and deeper, and on the other hand, requires additional measures to support their activities in such difficult economic conditions, etc.

\section{References:}

Arai, Yu.N. 2013. Social entrepreneurship at the beginning of the XXI century: basic concepts and country characteristics. Russian Management Journal, 1(11), 111-130.

Austin, J., Stevenson, Way-Skillern, J. 2010. Social and Commercial Entrepreneurship: Similarities and Differences. Bulletin of St. Petersburg University, Management series, 3, 115-145.

Bacq, S., Eddleston, K.A. 2018. A resource-based view of social entrepreneurship: how stewardship culture benefits scale of social impact. Journal of Business Ethics, 3(152), 589-611.

Barinova, V. 2018. Foreign experience in the development of social entrepreneurship and the possibility of its application in Russia. Moscow, Institute of Economic Policy named after E.T. Gaidar, 100.

Dees, J.G. 2001. The meaning of social entrepreneurship. Center for the Advancement of Social Entrepreneurship, Duke University's Fuqua School of Business, available online: http://www.caseatduke.org/documents/dees_sedef.pdf

Dikovitskaya, D.V. 2019. Analysis of approaches to the study of social entrepreneurship. Innovative development of the economy: trends and prospects, 1, 51-58.

Ferova, I.S., Kozlova, S.A. 2019. Social security in the structure of the country national security. Business. Education. Law: Bulletin of Volgograd business institute, 1(46), 95-103.

Golovko, M.V., Agapova, S.P., Antsibor, A.V., Sukhoveeva, A.A., Andreeva, O.V. 2019. Social entrepreneurship as a promising way to economic security. Dilemas contemporáneos: Educación, Política y Valores, S7, 33.

Inzelt, A., Xonka, L. 2017. Responsible approach to research and innovation in the business sector. Foresight, 4, 63-73.

Ivaschenko, N.P., Bulygina, N.I. 2019. Social entrepreneurship in Russia: current state and features of development, MIR (Modernization. Innovation. Development), 1(10), 114-132. 
Kickul, J., Lyons, Th. S. 2014. Social entrepreneurship. Mission is to make the world a better place. Moscow, Alpina Publisher, 154.

Makarevich, A.N., Sazonova, T.Yu. 2012. The Nature and Specificity of Social Entrepreneurship in Russia. Russian entrepreneurship, 13(24), 52-56.

Morozov, G.B. 2019. Legal regulation of entrepreneurial activity: a textbook for academic bachelor's degree. Moscow, Yurayt, 109.

Nikulina, M.A., Kolodiev, M.Yu. 2017. Social security in the Russian Federation: criteria, threats, areas of support, Historical, philosophical, political, and legal sciences, cultural studies, and art history. Questions of theory and practice, 4(78), 153-157.

Plotnikov, A.V. 2019. Social Entrepreneurship as an Economic Phenomenon in Russia and Abroad. Moscow Economic Journal, 7.

Romanova, T.F., Otrishko, M.O. 2020. Social entrepreneurship: the concept and the need for development Social entrepreneurship and non-profit organizations: current state, problems, and development prospects in a changing world. Moscow, Creative Economy, 488.

Schultz, V.L. 2020. Business Security: a textbook for universities. Moscow, Yurayt Publishing House, 316.

Stoffers, J., Gunawan, A., Kleefstra, A. 2018. Social Entrepreneurship, An International Perspective. Open Journal of Social Sciences, 6, 10-24.

Yakovets, T.Yu. 2017. Social security is the basis of Russian stability. Russia on the way to Russia: conceptual search and economic strategy. Moscow, Economic department of MSU named after M.V. Lomonosov, 271-273. 